\title{
Queen Elizabeth I: The Rhetoric of a Unique Paradoxical Image
}

\author{
Sihem Salah Garrouri \\ Department of Languages and Translation \\ Faculty of Science and Arts, Rafha \\ Northern Border University, Arar, Kingdom of Saudi Arabia
}

\begin{abstract}
This study aims at scrutinizing Elizabeth I's creation of a unique paradoxical image, demonstrating that her self-representation was often contradictory. As an unmarried female sovereign and being cognizant of her vulnerability, she employed a discourse of contradiction, an instrumental political asset to challenge Renaissance gender expectations. The discrepancy in Elizabeth's rhetoric is evident in her speeches, prayers, and poetry. This research suggests that the process of selfrepresentation was carefully and skillfully attained through the projection of conflicting depictions. It explores three erratic depictions: masculine and feminine, virgin and mother, and divine and human. This project provides evidence that in her struggle with her gender and with the Renaissance culture, Elizabeth's rhetorical strategy was the creation of paradoxical images, arguing that this clever tactic allowed her to circumvent the issue of gender, legitimize her rule, and craft a unique regal identity. Her approach to leadership was, particularly, effective because she recognized the bonds between representation, gender, authority, and language.
\end{abstract}

Key Words: discourse, Elizabeth I, gender, imagery, self- representation

Cites as: Garrouri, S. S. (2019). Queen Elizabeth I: The Rhetoric of a Unique Paradoxical Image. Arab World English Journal for Translation \& Literary Studies, 3 (1), 53-65.

DOI: http://dx.doi.org/10.24093/awejtls/vol3no1.4 
AWEJ for Translation \& Literary Studies Volume, 3 Number 1. February 2019

Queen Elizabeth I: The Rhetoric of a Unique Paradoxical Image

Garrouri

\section{Introduction}

In early modern England, female rule caused considerable consternation. Living in a patriarchal society whose very foundation was built upon the idea that women are naturally inferior to men and thus unfit to rule, Elizabeth I of England deliberately employed conflicting representational images to transcend the restrictions that the society placed on her gender. Indeed, she represented herself as chaste saint and passionate lover, divinely-anointed and human leader, King and Queen, weak and strong, prince and princess, male and female. Elizabeth was aware of the threat caused by a female monarchy, and thus she fashioned herself through a "multifaceted galley of dramatis personae" to overcome the constraints imposed by the patriarchal system (Montini, 2011, p. 70). Patriarchy is a form of oppression and discrimination that undermines potential female achievements. It deprived women from their merits and promoted male primacy.

This research aims at scrutinizing Elizabeth's creation of a unique paradoxical image, arguing that being cognizant of her vulnerability as an unmarried Queen regnant whose legitimacy is doubtful, Elizabeth utilized her rhetorical prowess to project herself as non- threatening and satisfy the various irreconcilable demands. The researcher shall suggest that the process of selffashioning was carefully and self- consciously attained through the rhetoric of paradox. She would, in addition, demonstrate that Elizabeth's conflicting identity reveals her insecurity and vulnerability and her perpetual attempt to persuade her subjects to accept female sovereignty, proving that the discourse of contradiction is an oblique political tactic to assist in the creation of a unique royal identity.

Foucault (1994) suggests that discourse, knowledge, and power are entwined. He contends that there is no possible exercise of power without a certain discourse. Elizabeth chose a discourse of contradiction by skillfully employing her eloquence. In this regard, McDiarmid (2007) argues that "eloquence [is] a way of exercising power" (p. 120). Accordingly, power and rhetoric are intertwined. It is necessary to define the word rhetoric as a complex concept. In this article, our consideration will be limited, and we will focus on rhetoric or what Shenk (2010) labels "Elizabeth's erudition" as a strategic approach to bolster her regal authority (p. 3). Wilson, the secretary of state in 1579, defines rhetoric in his book, The Arte of Rhetorique (1560), as "a learned, or rather an artificiall declaration of the mynd" (Mair, 1909, p. 1).

This definition is arguably important because it shows that the Queen deliberately and carefully designed her words to gain power. The verb learn means "to gain or acquire knowledge of or skill in [...] by study, experience" (Hanks \& Pearsall, 2010, p. 1004) and artificial means "produced by human beings rather than occurring naturally" (Hanks \& Pearsall, 2010, p. 89). Herman (2010) postulates that Elizabeth used her poetic skills as a means of shaping her political persona. Bello (2011) observes that poetry, "allows her to wield the weapons of insinuation and intimidation" (p. 117).

A considerable body of studies has examined Elizabeth's self- representation investigating her portraits, progresses, and entertainments; however, little attention has hitherto devoted to her variable images. In this essay, the focus will be on her words as a particularly significant evidence of her political self- fashioning. Montini (2011) maintains that her political persona is mainly

Arab World English Journal for Translation \& Literary Studies 
created through her utterances. Frye (1996) also asserts that she constructed herself using her linguistics talents. Her speeches, prayers, and poems are illustrative examples which prove that Elizabeth's voiced identity was paradoxically framed. The term paradoxical refers to the selfcontradictory and ambiguous self-representations. According to the Oxford Dictionary of English, paradox means a person who "combines contradictory features or qualities" (Hanks \& Pearsall, 2010, p. 1287). In other words, her depictions are self- contradictory.

A study of all the inconsistent images, would be beyond the scope of this paper, therefore, this work focuses on three conflicting depictions: masculine and feminine, virgin and mother, and divine and human. Before discussing these images, it is vital to define image. Williams (1983) defines image as the "perceived reputation" (p. 159). An image of Elizabeth means a representational depiction of the Queen. For this project, the focus will be on the rhetorical imagery she projected. In other words, images which are the product of metaphorical language, showing that there are many instances, as we shall see, where there are distinct controversial depictions to deal with the presumably strange situation of a childless, unmarried Queen.

\section{Masculine and Feminine Imagery}

When Elizabeth I ascended the throne of England in 1558 many doubted her ability to rule as effectively as a man. For example, the theologian Becon (1968) considered female monarchy evidence of God's disgrace or "an evident token of thine anger toward us Englishmen" (p. 227). Knox (1972), the Scottish reformer, had a more extreme attitude since he viewed female sovereignty as an unusual practice. He violently attacked it in his pamphlet The First Blast of the Trumpet against the Monstrous Regiment of Women (1558), claiming that female superiority is "repugnant to nature, contumely to God, a thing most contrarious to his reveled will and approved ordinance, and, finally it is a subversion of good order, of all equity and justice" (p. 9) .

Elizabeth's immediate task was to prove that these stereotypical attitudes are inadequate. The solution to defend her position as a monarch and Supreme Governor of the Church of England and silence her critics was to present herself as both king and Queen with masculine and feminine attributes. In her accession speech at Hadfield Palace, in 1558, she stated: "And as I am but one body naturally considered, though by His permission a body politic to govern" (Marcus, Mueller, \& Rose, 2000, p. 52). This is what Wagner- Wright (2012) accurately describes as a male mind inside a female body. She claimed that she had two bodies: a body natural and a body politic. Although her body natural was weak because of her sex, God gave her a powerful body politic to govern effectively. Hackett (1995) explains that the body politic is "the timeless and essence of monarchy" while the body natural is "the private, human, mortal body of the temporary incumbent" (p. 21).

Montini (2011) affirms that Elizabeth's body is not only divine, ideal, feminine, but it stands for the nation. She also appropriately gives evidence that Elizabeth's natural body and English geography are closely related. In fact, Elizabeth's "womanhood" prevented her from territorial expansion: " $[\mathrm{I}]$ have not sought to advance my territories and enlarge my dominions, for both opportunities hath served me to do it, and my strength was able to have done it. I acknowledge my womanhood and weakness in that respect" (Marcus et al., p. 329).

Arab World English Journal for Translation \& Literary Studies 
Here, she establishes a contrast between "strength" and "weakness". This reveals that she adopted this recurrent rhetorical device of paradox to cultivate her image. She overtly admits that she is weak. An underlying reason for her weakness is her sex. It seems that she endorsed the stereotypical attitudes towards women. Nevertheless, apparently, this erratic imagery is a strategic linguistic approach to show that her reign is no threat to sixteenth century gender expectations. Accordingly, Elizabeth proved a skilled orator who is conscious that eloquence is a mighty weapon. In this respect, Wilson (1560) contends that an orator requires three things teaching, delighting, and persuading (Mair, 1909).

Elizabeth seemed to understand the principles of eloquence fully and exploited them for potential political ends. Indeed, using the theory of the King's Two Bodies, she brilliantly persuaded her subjects that she had masculine and feminine features. As Levin (2013) speculates, she attributed a new gendered meaning to this doctrine and redefined the traditional view of gender roles. I would argue that this concept allowed her to create a distinct persona. Indeed, not only did Elizabeth appropriate female characteristics such as compassion, love, and restraint and male attributes as strength, wisdom, and bravery, but she came to realize the importance of playing the traditional matrimonial roles to show that her sovereignty posed no threat to the patriarchal society. Perhaps, her speech at Tilbury in 1588 is an illustrative example of masculine imagery:

I am come amongst you, as you see, at this time, not for my recreation and disport, but being resolved, in the midst and heat of the battle, to live and die amongst you all; to lay down for my God, and for my kingdom, and my people, my honor and my blood, even in the dust. (Marcus et al., p. 326)

Her claim that she was ready to spend her blood is a masculine Renaissance characteristic. Moreover, the battlefield was an exclusively male field. Being in the war context, every word was carefully chosen, projecting the image of a warrior who had enough courage to repel the Spanish invader. She enhanced her strength and bravery, a male attribute. She also emphasized her legislative, military, and royal powers by cautiously selecting her words which are resonant with power, elaborate in language, and influential in style to persuasively highlight her commitment to her kingdom and evoke patriotic emotions to encourage her troops. Her words proved effective because her army defeated the Spanish army.

Perhaps the most important statement is "I know I have the body of a feeble woman, but I have the heart and stomach of a king, and a king of England too" (Marcus et al., p. 326). She enhanced her regal strength and courage by establishing a contrast between having a weak body and masculine qualities. Montini (2011) states that, these two bodies were significantly effective political assets to appeal and control her subjects. Mueller (2001) explains that the heart was "both the seat of courage $[. .$.$] and the seat of the royal identity" whereas the stomach was "the organ for$ doing violent and distressful deeds deemed necessary like bloodshed" (p. 12). She presented herself as "prince", "woman", and "king". Here, masculine characteristics are fused in a female body, a reference to the doctrine of the two bodies. This speech provides visible evidence that Elizabeth employed conflicting identities to achieve credibility. It seems plausible to argue that rhetoric was a means of empowerment. In fact, Elizabeth was aware that she was under constant observation. Thus, she had to meticulously choose her words and use her eloquence as a political 
asset. Montini (2011) asserts that, using her rhetorical skills, the Queen staged her persona and impressed her audience. In her speech on November 1586, she declared: "We princes, I tell you, are set on stages, in the sight and view of all the world dully observed" (Marcus et al., p. 383). Elizabeth knew she was under constant observation, so she had to cautiously fashion herself.

Male imagery is also evident at the very beginning of her reign. In her coronation entry, she identified herself with Daniel. She thanked God: "I acknowledge that Thou hast dealt as wonderfully and as mercifully with me as Thou Didst with Thy true and faithful servant Daniel, Thy prophet" (Marcus et al., p. 55).Using simile, she initiated the projection of the image of a divinely ordained Queen. It was God who saved her from the brutality of her half-sister Mary I. Elizabeth also expressed publicly that she is male and female: "I have been your Prince in peace, so will I be in war [...]. The enemy perhaps may challenge my sex for that I am a woman" (Schama, 2009, p. 326).

It is worth noting that Elizabeth doubted her rhetorical abilities in her speech of $15^{\text {th }}$ March 1575: "If any look for eloquence, I shall deceive their hope; [...] my sex permits it not" (Marcus et al., p. 168). This is a rhetorical device especially that in some context eloquence was considered as a dubious way to gain approval through artificial means. This lack of eloquence is surpassed by divine providence and by being a prince. However, a thorough investigation of her words reveals her skill in rhetoric. Probably, she pretended to be ineloquent to surprise the listeners and thus foreground her linguistic abilities. Masculine and feminine imagery was also obvious in the golden speech in November 1601:

For myself, I was never enticed with the glorious name of a king or royal authority of a Queen, as delighted that God hath made me His instrument to maintain His truth and glory, and to defend His Kingdom from dishonor, and tyranny and oppression. (Marcus et al., p. 342)

Elizabeth casts herself as both King and Queen with kingly and queenly qualities, which would lead one to assume that she represents herself in a "newly gendered fashion" (Levin, 2013, p. 122). She deliberately referred to herself as God's instrument, a recurrent statement in her speeches. In this sense, to doubt her authority is a challenge to God's will. This shows that she employed a religious discourse to justify her rule. In her 1593 speech, she underlined her feminine virtues by comparing herself with other princes: "I will not compare with any of them in wisdom, fortitude, and other virtuous; but [...] in love, care, sincerity, and justice, I will compare with any prince that ever you had or ever shall have" (Marcus et al., p. 329). She projected herself as an affectionate, loving, sincere, and just Queen.

Frye (1996) contends that she exploited this theory of the King's Two Bodies to justify what she labels "engendering herself" (p. 13). The researcher would argue that it assists in casting a unique regal identity and deconstructing the patriarchal codes. The Queen referred to both her sex and rhetoric in January 1563,

Being a woman wanting both wit and memory, some fear to speak and bashfulness besides, a thing appropriate to my sex. But yet the princely seat and kingly throne wherein God ...

Arab World English Journal for Translation \& Literary Studies 
AWEJ for Translation \& Literary Studies Volume, 3 Number 1. February 2019

Queen Elizabeth I: The Rhetoric of a Unique Paradoxical Image

Garrouri

hath constituted me maketh these two causes to seem little in my eyes. (Marcus et al., p. 70)

Here, again, we notice that being both a prince and God's assistance would allow her to achieve shrewdness and remembrance. Obviously, she adopted the same way of reasoning when she referred to her lack of eloquence.

Hence, to define her female monarchy and avoid male resentment, Elizabeth relied on her rhetorical skills. Montini (2011) notes that her rhetoric alters identities of power and gender. The writer thinks she also did demonstrate that discourse and power are intrinsically related. She would suggest that this conflicting depiction was a clever method used by an intelligent and welleducated Queen who proved that monarchy is not gender limited. Instead of explicitly challenging and fiercely criticizing the Renaissance norms, she shrewdly proved that their beliefs are inadequate. She showed that once women were given the opportunity to lead nations, they would not lack the courage and wisdom to exercise authority as successfully as men. Clearly, then, the creation of paradoxical images is a strategic rhetorical device to overcome the social inadequacies. One explanation of the use of this erratic rhetorical pattern is her sex and legitimacy which were always the main obstacles that she had to transcend. Another possible explanation to this phenomenon of inconsistency is to be able to deal with new circumstance and address her subjects with the image they wanted to see. Elizabeth, seemingly, felt she should not only cast herself as male and female, but also she needed to project another conflicting image being both virgin and mother, a strategic political device for a female sovereign.

\section{Virginity and Motherhood Imagery}

In her struggle to overcome the deficiencies associated to her sex, Elizabeth projected herself as both a virgin Queen and a Protestant leader. Indeed, as Frye (1996) puts it, she was struggling for the meanings linked to her body, "the circumlocutions of powerlessness give way to the self-sufficient image of the Virgin Queen" (p. 39). It seems safe to argue that her body was utilized to transcend the limitations imposed by the culture of her times. Indeed, "her body is the center of political meaning" (Frye, 1996, p. 39). This part provides evidence that Elizabeth did portray herself as a Virgin Queen using her linguistic skills. It scrutinizes Elizabeth's selfrepresentation through her public speeches and prayers that illustrate the initiation of the virgin and the mother imagery.

In her response to a petition by the House of Commons in 1559 that urged her to hasten in marriage negotiations, she made it clear that she was the servant of God: "His service only". She concluded that she had already been "bound unto an husband, which is the kingdom of England" (Marcus et al., p.59). To convince the members of Parliament, she showed them her inauguration ring as a symbol of her metaphorical marriage with her nation: "I am married to the realm of England when I was crowned this ring" (Marcus et al., p. 65). In addition, she affirmed that England was her spouse and her subjects are her offsprings: "That I have no children: for every one of you, and as many as are English, are my children and kinsfolks" (Marcus et al., p. 59). Clearly, then, she utilized her gender to claim the appropriation of wifehood and motherhood, a clever approach to appeal to her subjects. She also referred to the notion of family as a highly valued institution in early modern England. "I am sworn when I married to the realm not to alter

Arab World English Journal for Translation \& Literary Studies 
AWEJ for Translation \& Literary Studies Volume, 3 Number 1. February 2019

Queen Elizabeth I: The Rhetoric of a Unique Paradoxical Image

Garrouri

the laws of it" (Marcus et al., p. 65). This proves that Elizabeth promoted the image of maternity to deal with the succession as a strikingly crucial political matter. However, Elizabeth decided to remain unwed.

Elizabeth's appropriation of sacred Christian symbolism, the Virgin Queen image, was created to surpass the challenges of gender constraints and enhance the assertion of imperial monarchy. She created the cult of the Virgin Queen as a political asset to gain admiration of her subjects, foster her authority, and declare her reluctance to experience matrimony (Doran, 2003). Therefore, this imagery is consciously adopted as a means of empowerment. Undoubtedly, she wisely utilized the emblems of virginity to face the prevailing negative cultural attitudes towards female ruler. Susan Doran (2003) admits that the Virgin Queen image did not appear at the beginning of Elizabeth's reign. Hackett (1995) postulates that until the-1570's, Elizabeth's subjects viewed Elizabeth's virginity as "being nubile, in a state preparatory to or ripe for matrimony" ( $p$. 73). Nonetheless, she started cultivating this image early in her reign. She fashioned herself as a virgin in her speech in February 1559: "I happily chose this kind of life in which I yet live, which I assure you for mine own part hath hitherto best contended myself and I trust hath been most acceptable by God" (Marcus et al., p. 56). She affirmed: "and in the end this shall be for me sufficient: a marble stone shall declare that a Queen, having reigned such a time, lived and died a virgin" (Marcus et al., p. 58). Using personification, "a marble stone shall declare", she promotes the imagery of virginity. It is worth noting that Mary's virginity is a Catholic dogma that reformers denied. It is a debatable subject between Protestants and Catholics. Therefore, it was risky to appropriate this imagery that reformers rejected. It reminds them of the Old Faith they reformed. Possibly, she wanted to silence the Catholic threat by cultivating an image of a virtuous Protestant leader they could admire. She became "a substitute for the Virgin Mary, filling a post-reformation gap in the psyche of the mass, who craved a symbolic virgin mother figure" (Hackett, 1995, p. 7). Elizabeth made it clear that she would never marry because she metaphorically married England. Latham (2011) affirms that this symbolic marriage allowed her to project herself as a praiseworthy virgin, worthy of admiration because she sacrificed herself for the welfare of her people.

In 1563, both the House of Commons and the House of Lords called on the Queen to marry to beget a child and secure the succession to the English throne. Although many English and foreign suitors courted her such as Philip II, Prince Eric of Sweden, Robert Dudley, Earl of Leicester, King Charles IX of France, Archduke Charles of Austria, Henri De Valois, Duke of Anjou, Francois De Valois, and Duke of Alençon, she did not marry. Additionally, marriage was a highly political issue, she could not decide alone; she needed her Privy Council's consent. More interestingly, she utilized the marriage issue as a "political weapon to entice suitors and to tame claimants to the throne" (Haigh, 1998, p. 17). For instance, she used the marriage proposal of Francis, Duke of Anjou as a political tactic to achieve an alliance with France and, thus, silence both the French and the Spanish threat.

Certainly, the Queen and her Council had to wisely consider the consequences of any matrimonial case because her husband would possibly have had a share in her power. Nonetheless, a closer examination of the marriage issue reveals that various reasons justified Elizabeth's reluctance to marry. First of all, she had seen the fates of her father's wives particularly the execution of her mother, Anne Boleyn, on a charge of adultery when she was not yet three years

Arab World English Journal for Translation \& Literary Studies 59 ISSN: 2550-1542 | www.awej-tls.org 
old. Her step mother, Catherine Howard, was also executed in 1542 for adultery. Furthermore, Lord Thomas Seymour, King Edward VI's maternal uncle and husband of her step-mother Catherine Parr had political ambitions and began courting Elizabeth who was a victim of his sexual abuse. He was accused of treason and executed in 1549. According to Susan Doran (1996), "emotional block", seemingly, partially explain her rejection of matrimony and determination to lead her nation alone. Nevertheless, psychological arguments are skeptical because they lack accuracy. In addition, her intimate relationship with some courtiers such as Robert Dudley shows that she suffered no psychological breakdowns. More importantly, however, her celibacy allowed her to promote the image of the virgin Queen and overcome the issue of gender. The language was an effective medium to achieve this very purpose. In her prayer, she proudly highlighted her distinctive physical and mental abilities:

Indeed, I am unimpaired in body, with a good form, a healthy and substantial wit, prudence even beyond other women, and beyond this, distinguished and superior in the knowledge and the use of literature and languages, which highly esteemed because unusual in my sex. Finally, I have been endowed with all royal qualities and with gifts worthy for a kingdom, and have been given these freely by Thee. (Marcus et al., p. 141)

This prayer demonstrates that Elizabeth deliberately projected herself as an exceptional, knowledgeable, and intelligent monarch. She emphasizes her extraordinary learning abilities. This is clear in the lexical choice which depicts her as a leader with "superior", "distinguished", and "unusual" qualities. She, furthermore, distanced herself from common women since she mastered both languages and literature. In short, she claimed that God gave her unique characteristics that allowed her to rule England. Thus, using her rhetorical talents she foregrounded her unique abilities. In Wilson's words, a skillful orator "must naturally haue a wit [...] and learne to bee ell stored with knowledge" (Mair, 1909, p. 4). Elizabeth's wit and learning allowed her attain eloquence. In this respect, Shenk (2010) declares that Elizabeth was a Queen of great wisdom, undeniably a learned Queen.

Eloquence helped Elizabeth to turn motherhood into a remarkably useful metaphor to achieve political gains (Muller, 2001). Elizabeth explicitly referred to the notion of motherhood: "shall you never have any a more mother than I mean to be unto you all" (Marcus et al., p. 72). To emphasize the idea that her subjects would not have a mother who resembles her, Elizabeth used the adverb of frequency "never" and exaggeration. In this way, she highlighted the exceptional maternal bond that related her to her people. Love, of course, is a feminine characteristic.

Elizabeth utilized the mother image which was stemmed from the Renaissance cultural world view to cement her rule because motherhood entails unlimited care, warmth, affection, and love. As Farrell (2003) explains, motherhood "is at once nurturant and demanding, personal and strategic" (p. xii). By claiming maternity, she enhanced the idea of mutual love. Hence, motherhood is a valuable effective approach to alter behavior (Farrell, 2003). This cultural conception of motherhood implies sacrifice and limitless dedication. Furthermore, motherhood is associated to the notions of fidelity and loyalty. Obviously, her maternal approach to monarchy aimed at cultivating love, loyalty, and obedience. She was cognizant that this strategy was effective for more crucial political ends, the acceptance of her power. 


\section{Divinity and Humanity Imagery}

Not only motherhood and virginity are illustrative examples of Elizabeth's paradoxically framed image, but divinity and humanity are also significant examples of the practice of inconsistency. To fully scrutinize these contradictory images, this part offers an analysis of relevant prayers and Elizabeth's poem On Monsieur's Departure which indicate that she employed the same religious discourse used by her critics to legitimize her authority and make it clear that women are capable of wielding power. Her strategic way is to rule by God's ordinance and claim being God's servant. Elizabeth projected the image of a divine ordained Protestant heroine to bolster her rule and surpass contemporary skepticism about female sovereignty. In her prayer, she openly asked God to help her to serve him: "illumine Thy holy face that, as I serve Thee" (Marcus et al., p. 136). She declared that she is God's deputy. In her prayers, she underlines her exceptional nature and her role as a Protestant leader:

Thou hast done me so special and so rare a mercy that, being a woman by my nature weak, timid, and delicate, as are all women, Thou hast caused me to be vigorous, brave, and strong in order to resist [...] peoples and nations who have conjoined, plotted, conspired, and made league against Thee. (Marcus et al., p. 157)

One obvious recurrent discourse is to cast herself an extraordinary figure with unique qualities, thus, distancing herself from other women. The prayer illustrates Elizabeth's rhetoric of contradiction. On the one hand, she acknowledges that she is a frail, diffident woman; on the other hand, she declares that she is strong, confident, and brave. Thanks to God's mercy, her inherent womanly weakness has been altered into exceptional qualities. That she appears strong enough to accomplish her roles is, in large part, the work of God who made her "so special", "so rare". Put simply, God gave her the power and ability required to lead her kingdom, resist biblical enemies, and issue Protestantism. This idea is also evident in her prayer:

O my God [...] who art accustomed to choose the weak things this world to confound and destroy the strong, persist [...] for the repose and the quietude of Thine afflicted Churchin giving me strength so that I, [...] may free Thy people of Israel from the hands of Thy enemies. (Marcus et al., p. 157)

Here again, the recurrent rhetorical use of paradox is visible. She underlines her frailty, yet surprisingly, she highlights her strength. Using apostrophe "O my God", she enhances her divine role. This is a protestant practice: while the reformers believed that worshipper could address God directly, Old Faith believers acknowledged the presence of intermediary priests. The prayer also reveals Elizabeth as submissive to God, holding power and doing the work of God, to emancipate people. She valued her rhetoric as a significant medium to recreate an identity. Nevertheless, it exposes a personal insecurity. It is worth noting the frequent reference to enemies in Elizabeth's prayers, a clever approach to achieve obedience. She is God's instrument to defeat His enemies. Accordingly, she set the debate not in human terms or opposition to a human monarch, but opposition to the divine. This also clear in another example:

Father most high [...] who hast appointed me as monarch of the British Kingdom, favor me by Thy goodness to implant piety and root out impiety, to protect freely willed religion, to destroy superstitious fear by working freely to promote divine service, and to spy out 
the worship of idols; and further, to gain release from the enemies as well as those who hate me- Antichrists, Pope lovers, atheists, and all persons who fail to obey Thee and me. (Marcus et al., p. 163)

She declares that her enemies were actually enemies of God. Probably, the juxtaposition of "Thee and me" serves an important purpose; it reveals that Elizabeth is God's deputy and, thus, any hostility to Elizabeth's rule would be regarded as opposition to God's will. The potential of listing the diverse duties that she had to perform, in addition, emphasizes her divine role. Above all, God placed her in the seat of governance "to promote divine service". To highlight her role, she repeats the same grammatical structure: the infinitive verb: "to implement", "to protect", "to destroy", "to spy out", "to gain".

The second English prayer, which ended the 1549 Prayer Book, supports the idea that she utilized her prayers to project herself as God's handmaid. She addressed God: "O Lord God, [...] hast chosen me Thy servant and Thy handmaid to feed Thy people and Thine inheritance" (Marcus et al., p. 319). It is a striking fact that she perpetually puts emphasis on divine favor to promote true religion. She depicts herself as a "servant" or "handmaid" by humbly showing God's grace and power. One obvious example of casting divine imagery is her prayer after the Armada victory in 1588:

I most humbly, with bowed heart and bended knees, do render my humblest acknowledgements, and lowliest thanks; and not the least for that the weakest sex hath been so fortified by Thy strongest help that neither my people might find lack by my weakness nor foreigners triumph at my ruin. (Marcus et al., p. 424)

Here also she states that she is simultaneously weak and strong. The regular use of superlatives was meant to qualify her in front of God "humblest", "lowiest", and "weakest", a menial subject in front of the power of God: "strongest". Elizabeth's recognition of her human nature in front of divinity is, of course, a representation of medieval hierarchy. She uses the stylistic device of a polyptoton. The word humble is used in two ways as an adjective and a superlative to show that she is modest and submissive to God. Similarly, the term weak is used as a noun and a superlative possibly to highlight the idea that though she is weak, God gave her the support and strength to lead her kingdom.

Elizabeth did also depict herself as a human experiencing love, suffering, and having human desires. Her poem, On Monsieur's Departure, which was probably written after the failure of the French Duke of Alençon's marriage negotiations, illustrates the idea of a paradoxically constructed image or what Cerasano and Wynne-Davies (1992) labels "a double self" (p. 8). It further demonstrates the gap between her private feelings and the monarchical requirements since she is torn between the call of duty and the demands of her heart. This "double self" is manifested through the use of antonyms such as love/ hate, freeze/ burned, content/ discontent, high/ low, and live/ die. The conflicting imagery of love/ hate and freezing / burning, created a fragmented- self who cannot express her passionate love publicly although privately she suffers a lot because of the departure of the anonymous "Monsieur". The poem reads,

I grieve and dare not show my discontent; 
I love, and yet I am forced to seem to hate

I do, yet dare not say I ever meant;

I seem stark mute, but inwardly do prate.

I am, and not; I freeze yet I am burned,

Since from myself another self I turned.

My care is like my shadow in the sun-

Follows my flying, flies when I pursue it.

Stands and lies by me, doth what I have done;

His too familiar care does make me rue it;

No means I find to rid him from breast,

Till by the end of things it be suppressed.

Some gentler passion slide into my mind

For I am soft, and made of melting snow;

Or be more cruel, love, and so be kind.

Let me or float or sink, be high or low;

Or let me live with some sweet content,

Or die and so forget what love e'er meant (Marcus et al., pp. 302- 303)

The poem demonstrates that Elizabeth represents herself as a human being governed by her instincts and passions. It also shows how she skillfully utilized her rhetoric for image-making. The repetitive syntactic structure of conjunction plus verb: "Or be", "or float", "or sink", "or die" and noun phrases "my discontent, my shadow", "my breast", "my mind" illustrates the gap between the outer and the inner contradictory sentiments. This contrast is more conspicuous when she confesses: "I do, yet dare not say", "I am, and not', "I freeze and yet I am burned", "myself another self I turned". Bell (2010) asserts, Elizabeth's words are "ludic, figurative, enigmatic, multifaceted, and open-ended [...] deeply rhetorical, or persuasive" (p. xii). This poem provides supportive evidence that she is paradoxically framed. It does also reinforce the idea that she depicts herself as human capable of love and hatred, experiencing happiness and sadness, and living and dying. The Queen denies the demands of her heart and succumbs to the will of her kingdom. She was seeking a striking platform from which to convince her reading public to recognize her suffering for her unfulfilled love and acknowledge her sacrifice for the welfare of her country. At the end of the poem, she weeps for her inability to satisfy her womanly desires and fulfill her monarchical duties (Bell, 2010).

\section{Conclusion}

Inconsistent self- representation is one of Elizabeth's effective strategies of power. She was exceptionally clever in her linguistic self- construction which is manifested in voicing 
contradictory depictions that allowed her to challenge gender restrictions and consolidate her female sovereignty. By exploring three sites of contradiction: male and female, virgin and mother, and divine and human, it becomes clear that Elizabeth employed her rhetorical talents as an instrumental political device to project her monarchy, impersonate various roles, and, thus, respond to all sorts of desires and demands. She chose not to play the traditional roles of wifehood and motherhood; rather she decided to perform unusual roles: the mother of her subjects, the wife of her kingdom, and the servant of God. Accordingly, the rhetoric of paradox enabled her to display a distinctive royal identity. It seems logical to conclude that through the rhetorical strategy of discrepancy, Elizabeth not only appropriated all identities, but also she redefined the notion of sovereignty, power, and gender. Nevertheless, her approach to leadership reveals her struggle for identity and meaning.

\section{About the Author:}

Dr. Sihem Garrouri is an Assistant Professor of English at Northern Border University, Saudi Arabia. She worked as a lecturer in The Higher Institute of Applied Studies in Humanities of Sbeitla, Kairouan University, Tunisia. She received her master and PhD from The University of Caen, Normandy, France. Her research interests include: Renaissance studies, the Elizabethan era, history of ideas and politics, and gender studies. ORCid ID: https://orcid.org/0000-0001-66004870

\section{References}

Becon, T. (1968). Prayers and Other Pieces of Thomas Bacon. John Ayre (Ed.), New York: Johnson Reprint Corporation.

Bell, I. (2010). Elizabeth I: The Voice of a Monarch. New York: Palgrave Macmillan.

Bello, D.D. (2011). Elizabeth and the rhetoric of courtly mystification. In Alessandra Petrina (Ed.), Queen and Country: The Relation between the Monarch and the People in the Development of the English Nation (pp.103-124). Oxford and New York: Peter Lang.

Cerasano, S.P. \& Wynne-Davies M. (1992). 'From myself, my Other Self I Turned': An Introduction. In Cerasano and Wynne-Davies (Eds.), Gloriana's Face: Women, Public and Private, In the English Renaissance (pp. 1-24). Detroit: Wane State University Press.

Doran, S. (2003). Virginity, divinity and power: The portraits of Elizabeth I. Doran and Freeman (Eds.), In The Myth of Elizabeth (pp. 171- 199). New York: Palgrave Macmillan.

Doran, S. (1996). Monarchy and Matrimony: The Courtships of Elizabeth I, London and New York: Routledge.

Farrell, K. (2003). Preface: the mysteries of Elizabeth I. In Farrell and Swain (Eds.), The Mysteries of Elizabeth I: Selections from English Literary Renaissance (pp. x- xix). Amherst \& Boston: University of Massachusetts Press.

Frye, S. (1996). Elizabeth I: The Competition for Representation (1993). New York and Oxford: Oxford University Press.

Hackett, H. (1995). Virgin Mother, Maiden Queen: Elizabeth I and the Cult of the Virgin Mary. Basingstoke: Macmillan Press LTD. 
Haigh, C. (1998). Elizabeth I. London and New York: Routledge.

Hanks, P., Pearsall, J., \& Stevenson Angus. (2010). Oxford Dictionary of English, Oxford: Oxford University Press.

Herman, P.C. (2010). Royal Poetrie: Monarchic Verse and the Political Imaginary of Early Modern England. New York: Cornell University.

Kelly, M. \& Foucault, M. (1994). Critique and Power: Recasting the Foucault/ Habermas Debate. Cambridge: MIT Press.

Knox, J. (1972). First Blast of the Tempest against the Monstrous Regiment of Women (1558), Amesterdam: Theatrum Orbis Terrarum.

Latham, B. (2011). Elizabeth I in Film and Television: A Study of the Major Portrayals. Jefferson, North Carolina: McFarland \& Company.

Levin, C. (2013). The Heart and Stomach of a King: Elizabeth I and the Politics of Sex and Power. Philadelphia: University of Pennsylvania Press.

Mair, G.H. (1909). Wilson's Arte of Rhetorique (1560), Oxford: Clarendon Press.

Marcus, L.S., Mueller, J., \& Rose, M.B. (2000). Elizabeth I: Collected Works, London: The University of Chicago.

McDiarmid, J.F. (2007). The Monarchical Republic of Early Modern England: Essays in Response to Patrick Collinson. Aldershot: Ashgate Publishing.

Montini, D. (2011). "As many as are, English are my children and kinsfolks": Elizabeth I and the rhetoric of the country". In Alessandra Petrina (Ed.), Queen and Country: The Relation between the Monarch and the People in the Development of the English Nation. Oxford and New York: Peter Lang.

Muller, J. (2001). Virtue and Virtuality: Gender in the Self- representation of Elizabeth I. The University of Chicago.

Schama, S. (2009). A History of Britain-Volume 1: At the Edge of the World? 3000 BC-AD 1603. London: The Bodley Head.

Shenk, L. (2010). Learned Queen: The Image of Elizabeth in Politics and Poetry. New York: Palgrave Macmillan.

Wagner-Wright, S. (2012). Common Denominators in Successful Female Statecraft: The Political Legacies of Queen Elizabeth I, Indira Gandhi, and Margaret Thatcher. A Journal of the Oxford Round Table, Vol. 2012, (1), 1-16.

Williams, R. (1983). Key Words: A Vocabulary of Culture and Society, New York: Oxford University Press.

Arab World English Journal for Translation \& Literary Studies 